\title{
Penetration of polar organic compounds through the blood-brain barrier
}

\author{
Huba Kalász ${ }^{1 *}$, Kamil Musílek$^{2}$, Kornélia Tekes $^{3}$ \\ From 17th Scientific Symposium of the Austrian Pharmacological Society (APHAR). Joint meeting with the \\ Hungarian Society of Experimental and Clinical Pharmacology (MFT) \\ Innsbruck, Austria. 29-30 September 2011
}

\section{Background}

The effect of polar organic xenobiotics in the central nervous system depends on blood-brain barrier (BBB) penetration of these compounds. Newly synthesized pyridinium aldoximes (K-compounds) are promising antidotes for organophosphate intoxications. However, being highly polar, their BBB penetration is questionable. Using an in vivo model we aimed to characterize the $\mathrm{BBB}$ penetration of $\mathrm{K}$-compounds.

\section{Methods}

Male Wistar rats were injected intramuscularly with various doses of pyridinium aldoximes, blood, cerebrospinal fluid (CSF), and brain samples were collected after 5, 15, 30, 60 and $180 \mathrm{~min}$. A recently developed and optimized RP-HPLC method was used for analysis. Samples of brain homogenate, blood serum and CSF were subjected to clean-up using precipitation by perchloric acid $(\mathrm{pH}<1)$ and centrifugation at $14,000 \mathrm{rpm}$ at $4^{\circ} \mathrm{C}$ for $20 \mathrm{~min}$. Before load onto Zorbax $\mathrm{Rx}-\mathrm{C} 18$ stationary phase, the $\mathrm{pH}$ of the supernatants was adjusted to 2 . As mobile phase a mixture of acetonitrile and aqueous buffer $\mathrm{pH} 4.5$, also containing ion-pairing agent, was used.

\section{Results}

Dose- and time-dependent BBB penetration of pyridinium aldoximes was experimentally found.

\section{Conclusions}

Dose- and time-dependent brain and CSF levels of these highly polar K-compounds following intramuscular administration suggest contribution of active transport

\footnotetext{
*Correspondence: drkalasz@gmail.com

'Department of Pharmacology and Pharmacotherapy, Semmelweis University, 1089 Budapest, Hungary

Full list of author information is available at the end of the article
}

or specific transporters in their $\mathrm{BBB}$ penetration. The $\mathrm{BBB}$ transport may also depend on the size and charge of the solutes.

\section{Acknowledgements}

The authors are grateful to Ms. Györgyike Guth for her skilful technical assistance.

\section{Author details}

'Department of Pharmacology and Pharmacotherapy, Semmelweis University, 1089 Budapest, Hungary. ${ }^{2}$ Department of Toxicology, University of Defence, 50001 Hradec Králové, Czech Republic. ${ }^{3}$ Department of

Pharmacodynamics, Semmelweis University, 1089 Budapest, Hungary.

Published: 5 September 2011

doi:10.1186/1471-2210-11-S2-A51

Cite this article as: Kalász et al:: Penetration of polar organic

compounds through the blood-brain barrier. BMC Pharmacology 201111 (Suppl 2):A51.
Submit your next manuscript to BioMed Central and take full advantage of:

- Convenient online submission

- Thorough peer review

- No space constraints or color figure charges

- Immediate publication on acceptance

- Inclusion in PubMed, CAS, Scopus and Google Scholar

- Research which is freely available for redistribution 